\title{
Not only size matters: achene morphology affects time of seedling emergence in three heterocarpic species of Anacyclus (Anthemideae, Asteraceae)
}

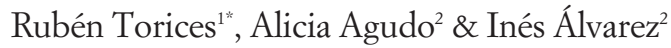 \\ ${ }^{1}$ Centro de Ecologia Funcional, Universidade de Coimbra, 3001- 455 Coimbra, Portugal \\ ${ }^{2}$ Real Jardín Botánico, CSIC(RJB-CSIC), Plaza de Murillo 2, E-28014 Madrid, Spain \\ rubentorices@gmail.com; agudo@rjb.csic.es; ines@rjb.csic.es
}

\begin{abstract}
Torices, R., Agudo, A. \& Álvarez, I. 2013. Not only size matters: achene morphology affects time of seedling emergence in three heterocarpic species of Anacyclus (Anthemideae, Asteraceae). Anales Jard. Bot. Madrid 70(1): 48-55.

The production of two or more distinct fruit types by an individual, i.e. heterocarpy, is considered as a mixed dispersal strategy in which a proportion of the offspring is able to colonize new sites, whilst others remain near the maternal location. Here, we aimed to explore the effects of achene morphology (winged vs. unwinged achenes) and achene size -measured here as achene mass- on post-dispersal life-history traits (probability and time of seedling emergence) in three heterocarpic Anacyclus species (Anthemideae, Asteraceae). Morphology, size and germination performance were studied in achenes from six populations of Anacyclus clavatus (Desf.) Pers., A. homogamos (Maire) Humphries, and A. valentinus L. Our results show that achene morphology and size were related to their position within the capitulum, such that outer, winged achenes were significantly heavier than the inner, unwinged ones. Additionally, winged achenes germinated faster than unwinged ones. This pattern may be related to the sequential achene time of release displayed by these species. Finally, our findings cast doubt on the role of wings as structures that favor dispersal by wind in these three species of Anacyclus.
\end{abstract}

Keywords: bet-hedging, Compositae, heterocarpy, mixed strategy, position effects, weeds, winged fruits.

\section{INTRODUCTION}

Seed dispersal is mainly determined by fruit characteristics, which usually vary continuously within an individual plant (Herrera, 2009). However, some plants produce two or more defined fruit types, a condition known as heterocarpy, in which distinct fruit morphs may show different behavior for dispersal, germination recruitment or seedling survival (Imbert, 2002). Heterocarpy is usually interpreted as a bethedging or mixed strategy in which different seed subsets of one individual may successfully germinate under different conditions in time and space. This offers the chance to colonize new sites, free from sibling competition or other local sources of stress, whereas the remainder of the offspring stays in the same habitat (Gadgil, 1971; Levin \& al., 1984; Schoen \& Lloyd, 1984; Venable \& Brown, 1993; Imbert \& Ronce, 2001). Various authors have proposed that a bet-hedging strategy is likely to be favored in temporally variable environments because it increases geometric fitness, even if indivi-

\section{Resumen}

Torices, R., Agudo, A. \& Álvarez, I. 2013. No sólo importa el tamaño: la morfología del aquenio afecta al tiempo de emergencia de la plántula en tres especies heterocárpicas de Anacyclus (Anthemideae, Asteraceae). Anales Jard. Bot. Madrid 70(1): 48-55 (en inglés).

La producción de dos o más tipos de frutos diferentes por un mismo individuo, i.e. heterocarpia, es considerada como una estrategia mixta de dispersión en la que una parte de la descendencia es capaz de colonizar nuevos sitios, mientras que la otra permanece cerca de la planta madre. En este trabajo, nuestro objetivo fue explorar los efectos de la morfología del aquenio (aquenios alados vs. no alados) y de su tamaño -medido aquí como masa del aquenio- en la etapa del ciclo de vida siguiente a la dispersión (probabilidad de germinación y tiempo de emergencia de las plántulas) de tres especies heterocárpicas del género Anacyclus (Anthemideae, Asteraceae). Se estudió la morfología, el tamaño y la germinación en aquenios de seis poblaciones de Anacyclus clavatus (Desf.) Pers., A. homogamos (Maire) Humphries y $A$. valentinus $L$. Nuestros resultados indican que tanto la morfología del aquenio como su tamaño estaban relacionados con su posición en el capítulo, de manera que los aquenios más externos -aladoseran significativamente más pesados que los internos -sin alas-. Además, los aquenios alados germinaron más rápidamente que los no alados. Este patrón puede estar relacionado con la liberación secuencial de los aquenios que ocurre en estas especies. Por último, nuestros resultados ponen en duda la función de las alas como estructuras que favorecen la dispersión por viento de los aquenios en estas tres especies de Anacyclus.

Palabras clave: bet-hedging, Compositae, heterocarpia, estrategia mixta, efectos de posición, malas hierbas, frutos alados.

dual phenotypes may have a relatively lower mean fitness (Gillespie, 1977; Venable, 1985; Venable \& al., 1987; Venable, 2007; Simons, 2011; Tielbörger \& al., 2012).

Among members of Asteraceae, the occurrence of heterocarpy is relatively high (Mandák, 1997; Imbert, 2002). Heterocarpic species in this family usually produce different achene morphs within the same capitulum (reviewed in Imbert, 2002), although exceptions in which achene variation occurs between aerial and subterranean capitula are known in Gymnarrbena micrantha (Koller \& Roth, 1964) and Catananche lutea (Ruiz de Clavijo, 1995; Ruiz de Clavijo \& Jiménez, 1998), and in Centaurea melitensis (Porras \& Muñoz, 2000) between cleistogamous and chasmogamous capitula. Apart from these exceptions, most of achene variation is found within capitula. Besides variation in morphology, achenes may also vary markedly in size (Venable \& al., 1987; McGinley, 1989; Maxwell \& al., 1994; Imbert \& al., 1996; Van Mölken \& al., 2005; Brändel, 2007). Both traits, achene size and morphology, usually covary, such that achenes without dispersal structures are usual- 
ly the heaviest ones, whereas those adapted for greater dispersal are generally lighter (McEvoy, 1984; Tanowitz \& al., 1987; Venable \& al., 1987; Imbert \& al., 1996; Imbert \& Ronce, 2001; Brändel, 2004, 2007; Bastida \& Menéndez, 2004, Bastida \& al., 2010; among others). With regard to germination performance, recent research suggests that variation in achene size may be the main driver of divergent behavior exhibited by seeds from different achene morphs (Van Mölken \& al., 2005; Torices \& Méndez, 2010). Achene size can also affects performance in post-dispersal life-history traits, particularly in competitive conditions (McEvoy, 1984; Andersson, 1996; Ruiz de Clavijo \& Jiménez, 1998; Meyer \& Carlson, 2001; Ruiz de Clavijo, 2005; Van Mölken \& al., 2005; Benard \& Toft, 2007). Alternatively, seeds might have different behaviors in germination that are linked to the achene morphology, regardless of size, and which might also affect later stages in plant development (Imbert, 2002). In order to distinguish which of these situations applies in any particular species, we need to determine whether the achene morphology within a capitulum has direct effects on post-dispersal life-history traits, or whether this effect is solely mediated by achene size.

In spite of the high incidence of heterocarpy in the Asteraceae and its known influence on dispersal ability and germination performance, the proximate causes of achene variation remain unknown. As part of an ongoing project focused on the reproductive biology and population genetics of the Anacyclus clavatus, $A$. homogamos and $A$. valentinus species complex, we studied achene size variation and seedling emergence in these three species. Anacyclus is a Mediterranean genus of mostly annual weedy herbs that show an extraordinary variation in flower, achene morphology and sexual expression within capitula and among species (Bello \& al., 2013). Achenes in Anacyclus vary from winged dorsiventrally flattened achenes to unwinged, from the outer to inner positions of the capitulum. Similar winged achenes are found in other Asteraceae (Anderberg \& al., 2007; Manchester \& O'Leary, 2010), mostly in the tribes Calenduleae (Garuleum, Norlindhia, Tripteris, etc.) and Heliantheae (Silphium, Verbesina, Wedelia, etc.). As far as we are aware, no studies have been conducted on the role of wings in these achenes. Bastida \& al. (2010) argued that the winged achenes in Anacyclus radiatus Loisel. may favor dispersion by wind. Bastida \& Menéndez (2004) found that in A. radiatus weight differ- ences between the central unwinged achenes and the peripheral winged ones were not significant and also both morphs had non-dormant seeds.

We aimed to explore the effects of achene morphology (presence vs. absence of wings in achenes) and achene size on two important post-dispersal life-history traits in three Anacyclus species: probability and time of seedling emergence. Finally, we discuss the implications that winged achenes may have on different dispersal mechanisms and germination performance with regard to bet-hedging strategies in Anacyclus life-history.

\section{MATERIAL AND METHODS}

\section{Study species and plant material}

Morphology, size and germination performance were studied in achenes from a total of 6 different natural populations in Anacyclus clavatus, $A$. homogamos, and A. valentinus (Table 1). A total of 9-10 mature capitula of several individuals in each site were collected and preserved in darkness at $-4{ }^{\circ} \mathrm{C}$ with silica gel until their use.

These three species (Fig. 1) occur in Western Mediterranean and their distribution areas partially overlap. Anacyclus clavatus is present throughout the Mediterranean both in coastal and inland areas, while $A$. homogamos is mainly restricted to inland areas of Morocco and Algeria, and A. valentinus is found in coastal areas throughout the Western Mediterranean (Humphries, 1979; pers. obs.). In areas where these species coexist, morphological variation of flowers increases remarkably (e.g., the presence or absence of ray flowers within populations). In $A$. bomogamos ray flowers are always lacking and all flowers are bisexual and tubular (i.e. hermaphroditic capitula), while $A$. clavatus and $A$. valentinus present female flowers in the periphery and hermaphroditic disc ones in the rest of the capitulum (i.e. gynomonoecious capitula). Furthermore, while $A$. clavatus shows female ray flowers, in $A$. valentinus these are inconspicuously rayed to rayless and fewer in number.

\section{Acheneposition and size}

Each capitulum was manually opened up to separate the achenes, which were classified depending on their relative position within each capitulum in one of 5 categories (from the

Table 1. Sites and sampling for the three studied species of Anacyclus.

\begin{tabular}{|c|c|c|}
\hline Species & Origin/Voucher & Sampling \\
\hline \multirow[t]{2}{*}{ A. clavatus } & $\begin{array}{l}\left.\text { Spain: Granada, Carchuna (36² } 41^{\prime} 49^{\prime \prime} \mathrm{N} ; 3^{\circ} 27^{\prime} 33^{\prime \prime} \mathrm{W}\right) \text {, } \\
13 \text { m, Agudo } 1\end{array}$ & $\begin{array}{l}\text { one capitulum from each of } 10 \text { individuals } \\
\text { (late summer 2011) }\end{array}$ \\
\hline & 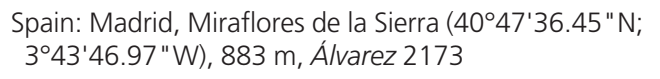 & $\begin{array}{l}\text { one capitulum from each of } 10 \text { individuals } \\
\text { (early autumn 2011) }\end{array}$ \\
\hline \multirow[t]{2}{*}{ A. homogamos } & $\begin{array}{l}\text { Morocco: Imouzzer (3119'55 "N; 7²4'32 "W), } \\
2224 \text { m, Gonzalo } 1275\end{array}$ & $\begin{array}{l}10 \text { capitula from an unknown number } \\
\text { of individuals (summer 2009) }\end{array}$ \\
\hline & $\begin{array}{l}\text { Morocco: Asni }\left(31^{\circ} 15^{\prime} 4^{\prime \prime} \mathrm{N} ; 7^{\circ} 58^{\prime} 40^{\prime \prime W}\right) \\
1160 \mathrm{~m} \text {, Álvarez } 2115\end{array}$ & $\begin{array}{l}9 \text { capitula from an unknown number } \\
\text { of individuals (late spring 2010) }\end{array}$ \\
\hline \multirow[t]{2}{*}{ A. valentinus } & $\begin{array}{l}\text { Spain: Girona, Castelló d'Empuries (42¹5'47.2 "N; } \\
3^{\circ} 7^{\prime} 45.5^{\prime} \text { "E), } 0 \text { m, Álvarez } 2059\end{array}$ & $\begin{array}{l}10 \text { capitula from } 3 \text { individuals } \\
\text { (summer 2009) }\end{array}$ \\
\hline & $\begin{array}{l}\text { Spain: Málaga, Iznate }\left(36^{\circ} 46 \text { '35 " N; 4¹0'45 "W), }\right. \\
285 \text { m, Álvarez } 2137\end{array}$ & $\begin{array}{l}\text { one capitulum from each of } 9 \text { individuals } \\
\text { (late summer 2011) }\end{array}$ \\
\hline
\end{tabular}



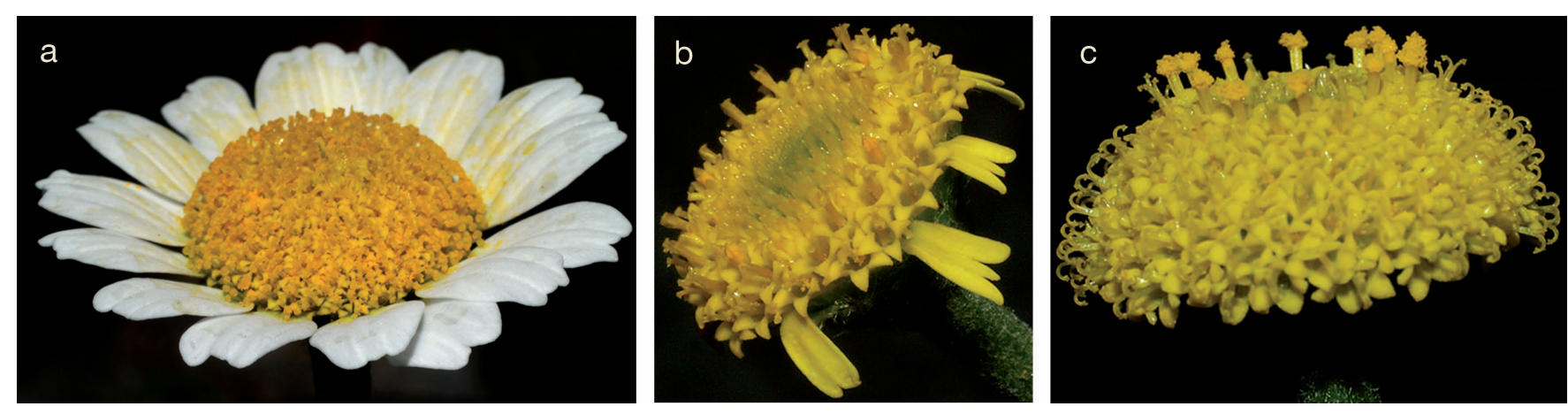

Fig. 1. Morphological variation among the capitula of the studied species of Anacyclus: a, Anacyclus clavatus; b, A. valentinus; c, A. homogamos (photograph: J. Fuertes).

outermost positions to the innermost): (1) winged, and produced by female peripheral flowers (only present in $A$. valentinus and $A$. clavatus), (2) outermost winged, (3) innermost winged, (4) outermost unwinged, and (5) innermost unwinged. Achene size was measured as achene mass. Since achenes were very light $(<0.1 \mathrm{mg})$, groups of ten were weighed for each category in all capitula using a Kern ABJ electronic precision balance $(0.1 \mathrm{mg})$.

\section{Achene morph and seed germination}

Our aim was to study seed germination behavior in clearly distinct achene morphs: winged vs. unwinged achenes. Consequently, we selected only the outermost achenes which displayed the largest wings (excluding those achenes from female flowers) so as to have the same kind of achenes across all species, since $A$. bomogamos does not have female flowers, and the innermost achenes, which never showed wings (Fig. 2). Five fertile achenes (i.e. achenes that were slightly swollen and hard, resistant to tweezers pressure) of each category in each capitulum were selected for study totaling 580 achenes. They were sowed on wet filter paper into Petri dishes and maintained under a $16 \mathrm{~h}$ light, $8 \mathrm{~h}$ dark regime and temperature ranging $10^{\circ}-27^{\circ} \mathrm{C}$ in a glasshouse at the Real Jardín Botánico, CSIC. Filter papers were kept moist throughout

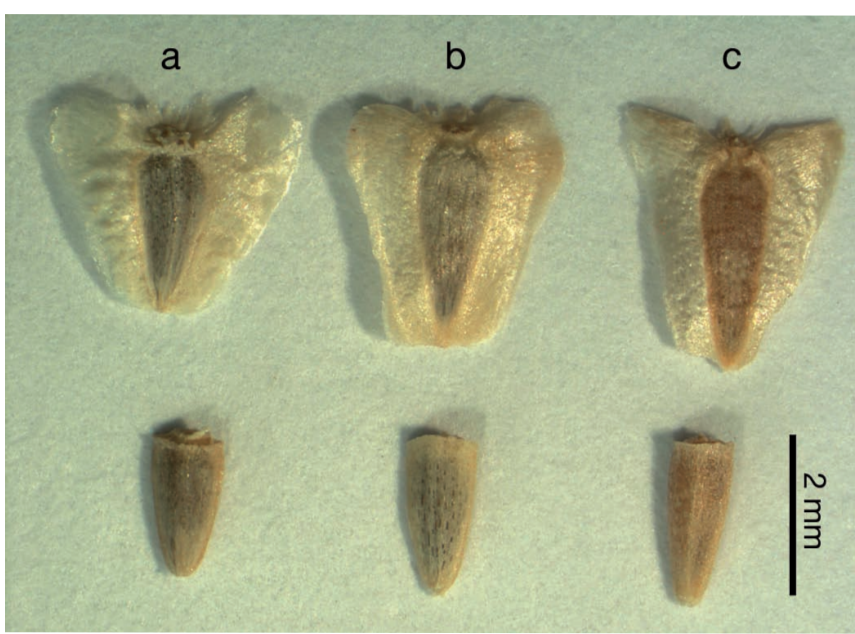

Fig. 2. Heterocarpy (winged vs. unwinged) in achenes of the studied species: a, Anacyclus clavatus, b, A. valentinus, c, A. homogamos. the study. The experiment was initiated on 20th January 2012 and seed germination was recorded daily until the experiment was terminated at 120 days.

\section{Statistical analyses}

We evaluated how position, which was completely correlated with achene morphology, influenced achene size, and afterwards, whether achene morphology and/or achene size affected seed germination traits. Firstly, to assess the effect of the achene position/morphology on achene size, we fitted Generalized Linear Mixed Models (GLMMs), via restricted maximum likelihood (Patterson \& Thompson, 1971). GLMMs were employed because they provide a flexible way to model traits allowing the distinction between fixed and random factors in the model at the same time vs. a standard linear modeling. Satterthwaite's method was used to determine the approximate denominator degrees of freedom for these tests (Verbeke \& Molenberghs, 1997). The explanatory variables included in the model were achene position, site and its interaction (achene position $\times$ site), whereas capitulum was included as a random factor. The response variable, achene size, was modeled using a gamma distribution with a log link function.

Secondly, we also evaluated the effects of achene morphology and achene size on the probability of seed germination and time of germination by fitting GLMMs. In these two cases the explanatory variables were achene size, achene morphology, site and its interaction (achene morphology $\times$ site). Again, the capitulum was the random factor. The probability of germination was modeled using a binomial distribution with a logit link function and time of germination was modeled using a Poisson distribution with a log link function. A different model for each species was fitted. All models were fitted using the GLIMMIX procedure of SAS (SAS Institute, Cary, NC) with the DIFF option in the LSMEANS statement.

\section{RESULTS}

\section{Achene size variation}

Achene size decreased from outermost/winged to innermost/unwinged positions in all three species at all studied sites (Table 2, Fig. 3). Furthermore, achene size also differed within two of the three species (Table 2). In A. clavatus, ache- 
Table 2. Effects of flower position and population on achene size of three Anacyclus species.

\begin{tabular}{|c|c|c|c|c|c|c|}
\hline \multirow[b]{2}{*}{ Fixed factors } & \multicolumn{2}{|c|}{ A. clavatus } & \multicolumn{2}{|c|}{ A. valentinus } & \multicolumn{2}{|c|}{ A. homogamos } \\
\hline & $F$ & $P$ & $F$ & $P$ & $F$ & $P$ \\
\hline Position & $70.15_{4,71}$ & $<0.0001$ & $35.00_{4,62.04}$ & $<0.0001$ & $20.37_{3,39}$ & $<0.0001$ \\
\hline Site & $4.071,18.0$ & 0.0589 & $5.44_{1,16.92}$ & 0.0322 & $0.88_{1,13}$ & 0.365 \\
\hline Position $\times$ Site & $1.264,71$ & 0.2953 & $0.84_{4,62.04}$ & 0.5034 & $1.38_{3,39}$ & 0.2618 \\
\hline Random factor & Estimate & $S E$ & Estimate & $S E$ & Estimate & $S E$ \\
\hline Capitulum & 0.047 & 0.017 & 0.050 & 0.019 & 0.035 & 0.015 \\
\hline Sample size & \multicolumn{2}{|c|}{99} & \multicolumn{2}{|c|}{89} & \multicolumn{2}{|c|}{60} \\
\hline
\end{tabular}

Data represent the Wald-type F-statistic with the degrees of freedom as subindex for fixed factors (the sign indicating the direction of the effects), and the estimate for covariance parameter and its standard error for the random factor.

nes from Carchuna were significantly heavier than those from Miraflores de la Sierra, and likewise in A. valentinus those from Iznate were heavier than those from Castelló d'Empuries. Despite these differences, a general tendency for achene weight to decline towards inner positions was observed for each respective pair of sites (Fig. 3). In A. homogamos this tendency was less marked since only the innermost achenes were statistically different from the rest (Fig. 3).

\section{Seed germination probability of winged vs. unwinged achenes}

Mean percentage of total germination in all species analyzed was relatively high $(74 \%)$, while variation in observed germination within and among species was low. Seeds of winged vs. unwinged achenes did not show different germination probabilities for most of the sites (Table 3, Fig. 4a), with the exception of seeds of winged achenes from one site of $A$. clavatus (Miraflores) that germinated at a significantly lower percentage than unwinged ones, although seeds of winged achenes from this site germinated at the very high rates found in the other two species (Fig. 4a). Achene size influenced positively the probability of seed germination in one species, A. clavatus (Table 3 ).

Additionally, our analyses indicated that the probability of germination was significantly different between sites within species (i.e.: $54 \%$ in Carchuna vs. $91 \%$ in Miraflores de la Sierra for A. clavatus; $66 \%$ in Asni vs. $94 \%$ in Imouzzer for A. homogamos; $56 \%$ in Iznate vs. $85 \%$ in Castelló d'Empuries for $A$. valentinus; Table 3 ).

\section{Seedling emergence time of winged $v$ s. unwinged achenes}

Seeds showed an extraordinary variation in germination times, from one day after being sowed to more than 90 days. This variation was associated to achene morphology within each capitulum, so that in general, seeds of winged achenes germinated much faster than those of unwinged ones (Table 4, Fig. 4b). Only achenes of $A$. clavatus from Miraflores did not show this pattern (Fig. 4b). Time of seedling emergence varied significantly among sites in $A$. clavatus and $A$. bomo-

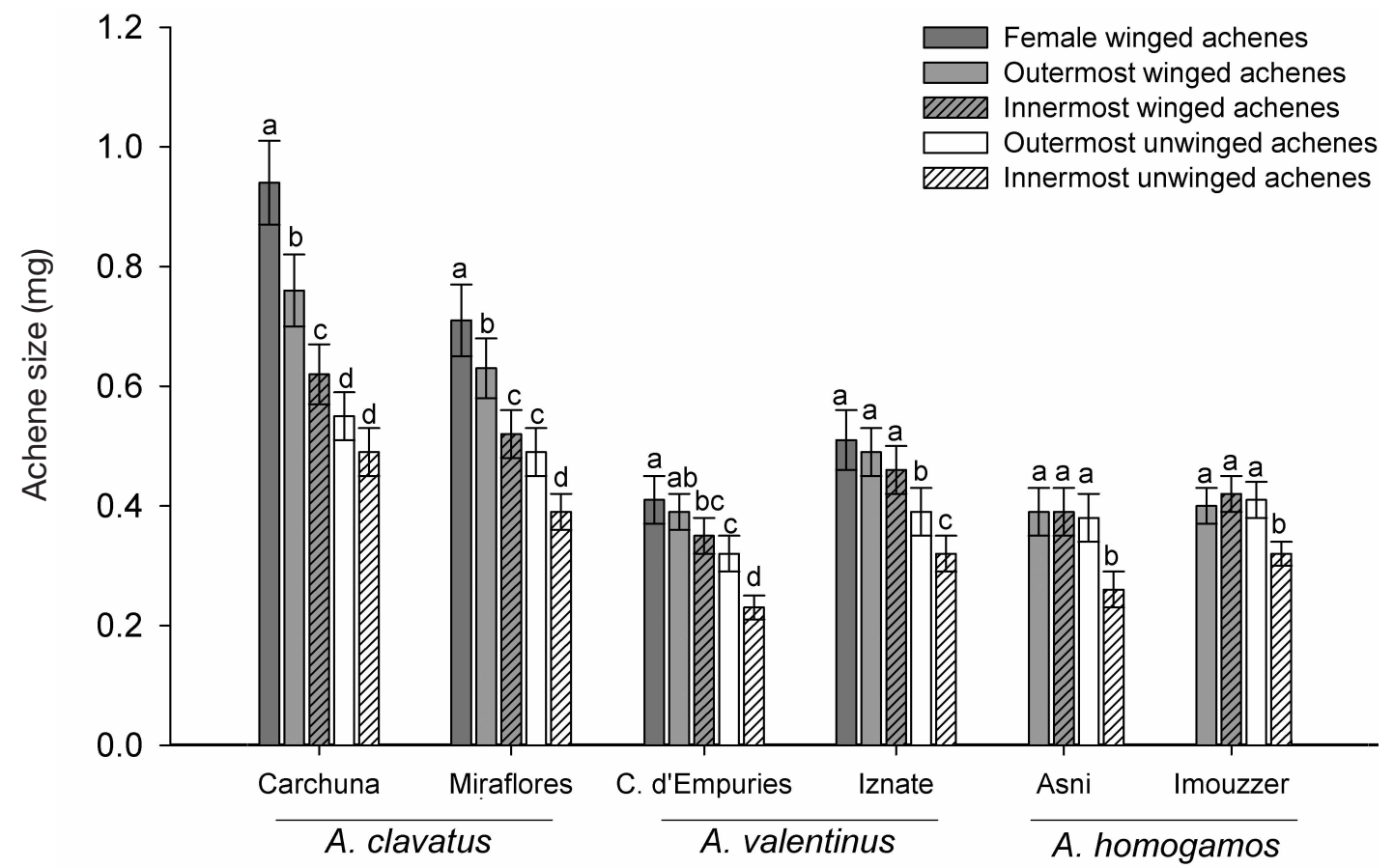

Fig. 3. Least-square means ( $\pm \mathrm{SE}$ ) of achene size of three species of Anacyclus from two sites each, and from different position within capitula. Means sharing a superscript were not significantly different at the $P<0.05$ level. 
Table 3. Effects of achene morphology, achene size, and population on germination probability of three Anacyclus species.

\begin{tabular}{|c|c|c|c|c|c|c|}
\hline \multirow[b]{2}{*}{ Fixed factors } & \multicolumn{2}{|c|}{ A. clavatus } & \multicolumn{2}{|c|}{ A. valentinus } & \multicolumn{2}{|c|}{ A. homogamos } \\
\hline & $F$ & $P$ & $F$ & $P$ & F & $P$ \\
\hline Morphology & $0.73 \quad 1,45.8$ & 0.3983 & $0.23_{1,68.6}$ & 0.6361 & $2.54_{1,149}$ & 0.1131 \\
\hline Site & $13.29 \quad 1,18.5$ & 0.0018 & $4.71 \quad 1,15.6$ & 0.0458 & $11.88 \quad 1,11.9$ & 0.0653 \\
\hline Morphology $\times$ Site & $7.911,190$ & 0.0054 & $1.47 \quad 1,188$ & 0.2267 & $0.641,149$ & 0.4239 \\
\hline Achene size & $+6.271,24.1$ & 0.0194 & $0.25_{1,23.51}$ & 0.6240 & $0.00_{1,26.3}$ & 0.9840 \\
\hline Random factor & Estimate & $S E$ & Estimate & SE & Estimate & $S E$ \\
\hline Capitulum & 1.725 & 1.086 & 1.279 & 0.793 & 1.140 & 1.048 \\
\hline Sample size & \multicolumn{2}{|c|}{195} & \multicolumn{2}{|c|}{193} & \multicolumn{2}{|c|}{154} \\
\hline
\end{tabular}

Data represent the Wald-type F-statistic with the degrees of freedom as subindex for fixed factors (the sign indicating the direction of the effects), and the estimate for covariance parameter and its standard error for the random factor.

gamos, but not in A. valentinus (Fig. 4b; Table 4). Thus, those sites having the fastest germinating seeds (Miraflores and Imouzzer) also showed smaller differences in germination time between seeds of winged vs. unwinged achenes (Fig. 4).

Achene morphology influenced the time of seedling emergence. However, whilst achene size had no significant effect in $A$. homogamos, in $A$. valentinus and $A$. clavatus, both achene size and morphology significantly influenced seedling emergence times, although in $A$. clavatus the effect of achene
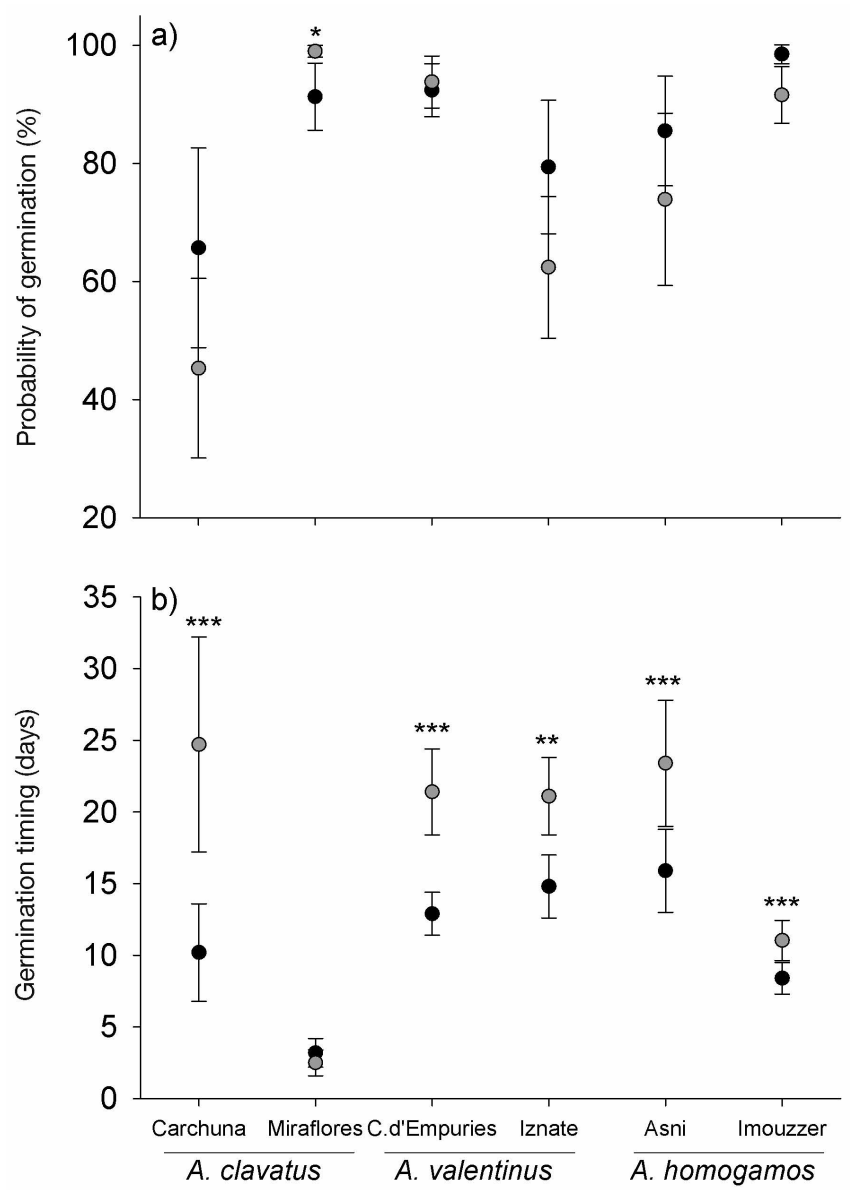

Fig. 4. Least-square means ( $\pm \mathrm{SE})$ of a) probability of germination, and b) germination timing of winged (black) and unwinged (grey) achenes of three species of Anacyclus from two sites each. Significant differences among winged and unwinged achenes are shown above each site ${ }^{*}<$ $\left.0.05,{ }^{* *}<0.01, * * *<0.001\right)$. morphology also depended on the site (Table 4). Beyond the significant effect of achene size on emergence time in these two species, achene morphology, with the exception of $A$. clavatus at the Miraflores site, also affected seedling emergence times, indicating that achene morphology could have a direct effect on the timing of germination independent to that of achene size in these three species (Table 4).

\section{DISCUSSION}

\section{Achene size and morphology: their implications in dispersal}

Our results show that in these three species of Anacyclus, achene size is related to position on the capitulum, so that outer achenes are significantly heavier than inner ones, as commonly occurs in other heterocarpic Asteraceae (McEvoy, 1984; Venable \& al., 1987; McGinley, 1989; Maxwell \& al., 1994; Imbert \& al., 1996; Imbert, 2002; Brändel, 2007; Sun \& al., 2009; Filho \& Takaki, 2011; but see Rocha, 1996). Usually, in such heterocarpic species, variation in achene size and position is also correlated to the presence or absence of dispersal structures within the same capitulum. In Anacyclus clavatus, $A$. bomogamos and $A$. valentinus, winged achenes were heavier than unwinged ones. This situation seems contrary to that found in most heterocarpic species in which achenes presenting structures to favor dispersion by wind (e.g. pappus) are the lightest. Therefore, the role of achene wings in Anacyclus dispersal is unclear. Although in A. radiatus achene size does not vary within a capitulum, Bastida \& al. (2010) suggest that winged achenes in this species might be secondarily dispersed by wind.

Winged fruits and/or seeds are considered to be wind dispersed because wings reduce the descent rate of diaspores (Harper, 1977; Van der Piil, 1982; Cousens \& al., 2008). Although morphology may help to understand how diaspores disperse, the conventional assignment of a plant species to a particular mode of dispersal based only on the morphology of its diaspores could result in misleading conclusions (Tackenberg \& al., 2003). Several lines of evidence indicate that wind may be only one of several possible vectors of dispersal of Anacyclus achenes. Firstly, the very low height of Anacyclus species (almost always below $1 \mathrm{~m}$ ) limits the effective dispersal by wind, since wind dispersal is strongly correlated with plant height (Thomson \& al., 2011). Secondly, in Anacyclus, achenes are protected by the persistent involucral bracts such 
Table 4. Effects of achene morphology, achene size, and population on time of seedling emergence of three Anacyclus species.

\begin{tabular}{|c|c|c|c|c|c|c|}
\hline \multirow[b]{2}{*}{ Fixed factors } & \multicolumn{2}{|c|}{ A. clavatus } & \multicolumn{2}{|c|}{ A. valentinus } & \multicolumn{2}{|c|}{ A. homogamos } \\
\hline & $F$ & $P$ & $F$ & $P$ & $F$ & $P$ \\
\hline Morphology & $2.03_{1,147}$ & 0.1563 & $19.47_{1,151}$ & $<0.0001$ & $22.06_{1,133}$ & $<0.0001$ \\
\hline Site & $15.921,17.4$ & 0.0009 & 0.12 & 0.7299 & $10.06_{1,13.2}$ & 0.0072 \\
\hline Morphology $\times$ Site & $47.79_{1,147}$ & $<0.0001$ & $3.301,151$ & 0.0714 & $1.20_{1,133}$ & 0.2750 \\
\hline Achene size & $-42.301,147$ & $<0.0001$ & $-17.21_{1,151}$ & $<0.0001$ & $1.64_{1,133}$ & 0.2022 \\
\hline Random factor & Estimate & $S E$ & Estimate & $S E$ & Estimate & $S E$ \\
\hline Capitulum & 0.799 & 0.304 & 1.226 & 0.047 & 0.150 & 0.062 \\
\hline Sample size & \multicolumn{2}{|c|}{152} & \multicolumn{2}{|c|}{156} & \multicolumn{2}{|c|}{138} \\
\hline
\end{tabular}

Data represent the Wald-type F-statistic with the degrees of freedom as subindex for fixed factors (the sign indicating the direction of the effects), and the estimate for covariance parameter and its standard error for the random factor.

that dry capitula become resistant structures that may remain on dead plant for long periods of time, resulting in an aerial seed bank (Bastida \& al., 2010; pers. obs.). This type of capitulum is present in other Asteraceae that grow in arid and semi-arid environments (Zohary, 1950), in which moisture seems the main factor for achene release (i.e., ombrohydrochory). Achenes are retained in the capitula until the rainy season, and are then sequentially released during different periods of rain (Gutterman \& Ginott, 1994, in Asteriscus pygmaeus (DC.) Coss. \& Durieu; and Aguado \& al., 2012, in Anthemis chrysantha Gay). This mechanism may be advantageous in fluctuating environments such as Mediterranean Climate zones because it increases the probability of establishment during different pulses of precipitation when the likelihood of establishment success is maximal (Gutterman, 1994; Peters \& al., 2009). A similar mechanism was described in A. radiatus (Bastida \& al., 2010), and observed in other Anacyclus species, in which achenes dampened by rain are released centripetally, so that unwinged inner achenes may be liberated several months after the outermost. Consequently, it is expected that heavy rains rather than winds may be the main dispersal vector in all such ombrohydrochorous species. Furthermore, small diaspores, such as Anacyclus achenes, usually show a high capacity to float which may allow secondary dispersal by temporary watercourses (e.g. Telenius \& Torstensson, 1989; Redbo-Torstensson \& Telenius, 1995; Fumanal \& al., 2007; Cousen \& al., 2008; Lu \& al., 2010). Finally, capitula with some achenes persisting (the aerial seed bank) can be observed after the rainy season when conspecific individuals are in flower. These capitula also might act as dispersal units attached to animals (goats, sheep, etc.) or by human activity (transport by roads and/or railroad). In this way, various agents may contribute to achene dispersal apart from winds, and the effective dispersal of each achene morph will depend on which dispersal agent(s) is predominant.

\section{The effects of achene morphology on seedling emergence}

Achene morphology and size influenced different stages of the post-dispersal life-history traits in these Anacyclus species, supporting previous findings on direct and indirect effects. The probability of seed germination was mainly related to achene size rather than achene morphology in A. clavatus. Within an individual, seeds of larger achenes usually showed a higher probability of germination than those of smaller ones
(Rai \& Tripathi, 1982; Pandey \& Dubey, 1988), regardless of the achene dispersal ability (McEvoy, 1984). Such differences in germination have been mainly attributed to seed size rather than to differences in achene morphology (Van Mölken \& al., 2005).

In contrast, timing of seedling emergence in all the studied species was directly influenced by morphology. Thus, independently of achene size, seeds of winged achenes germinated faster than those from unwinged ones. This pattern may have resulted from a coupling of seedling emergence to the sequential mechanism of capitulum opening and achene release displayed by these species. Consequently, we would expect a divergent selection on seedling emergence times of outer winged achenes vs. inner unwinged ones, leading to a mixed strategy in germination. However, since morphology and position within capitula are fully coupled, we cannot disentangle at present whether the observed effects should be solely attributed to achene morphology or to its position within a capitulum. To answer this question, manipulative experiments on wing size would be needed to assess the potential effects of winged morphology, achene position and achene size on emergence times in this genus.

The differences in the timing of seedling emergence of winged vs. unwinged achenes may also influence the potential dispersal distance of each achene morph. If the main dispersal agent is a passive one such as water and/or wind, then, the time of exposure to dispersal vectors might influence the final ability of achieving longer distances, such that unwinged achenes have more time to be secondarily dispersed once they have been released from capitula. By contrast, seed of winged achenes germinate quickly, sometimes within $24 \mathrm{~h}$, thus reducing the probability of being secondarily long-dispersed. This reduction in the probability of secondary dispersal occurs in other species with diaspores released by rains in harsh environments (Parolin, 2006). Thus, contrary to expectation, the heavier winged achenes might achieve shorter, or at least similar distances to the unwinged and lighter ones. Whether achene release and achene variation in emergence times are adaptive strategies developed through selection to cope with unpredictable rains and disturbed habitats, we would expect that both traits (1) vary along a gradient of unpredictability in rains, and (2) were hereditable in some way.

An alternative explanation for the rapid germination of winged achenes might be an adaptive response triggered by competence with neighbors. It is expected that accelerated 
germination is selected when competition in the neighborhood is likely to be high (Orrock \& Christopher, 2010). In another Asteraceae, Crepis sancta, early emergence of heavier achenes provides a competitive advantage that might have been selected to cope with sibling competition (Dubois \& Cheptou, 2012). Thus, winged achenes may be adapted to compete with siblings rather than to be long dispersed since they are able to germinate rapidly. But then, does having wings have any adaptive significance beyond dispersal? Wings might contribute to the ecophysiological mechanism by means of which the time of seedling emergence is controlled, because they are membranous expansions of the pericarp that increase the surface through which water and gas can enter into the embryo to initiate germination. It is known that the timing of germination can be influenced by the pericarp anatomy of achenes (Imbert, 2002). For instance, thick pericarps restrict gas exchange and water absorption by the embryo tissue (McEvoy, 1984; Tanowitz \& al., 1987; Prinzie \& Chmielewski, 1994).

Despite our lack of knowledge of the effective dispersal agent(s) for each achene morph type, several traits (i.e., high percentage of germination, non-dormancy, fast seed germination rate of the first subset of achenes released, lack of a seed soil bank, and differences in seedling emergence coupled with achene release) are consistent with a bet-hedging strategy that ensures progeny establishment in different optimal germination frames.

\section{ACKNOWLEDGEMENTS}

This research is part of the project "Evolution in Anacyclus L. (Anthemideae, Compositae). Analysis of the A. clavatus (Desf.) Pers. and A. valentinus $\mathrm{L}$. contact zone", funded by the Ministry of Science and Innovation, Spain (Plan Nacional de I+D+I, CGL2010-18039). We thank A. Herrero and A. Afonso for their technical assistance, to R. Rubio de Casas and L. DeSoto for their valuable comments on manuscript. AA and RT are currently supported by a predoctoral FPI scholarship (BES-2011-048197) and a postdoctoral scholarship (BVA 2010-0375) respectively, from the Spanish Ministry of Education.

\section{REFERENCES}

Aguado, M., Vicente, M.J., Miralles, J., Franco, J.A. \& Martínez-Sánchez, J.J. 2012. Aerial seed bank and dispersal traits in Anthemis chrysantha (Asteraceae), a critically endangered species. Flora 207: 275-282.

Anderberg, A.A., Baldwin, B.G., Bayer, R.G., Breitwieser, J., Jeffrey, C., Dioon, M.O., Eldenas, P., Funk, V., Garcia-Jacas. N., Hind, D.J.N., Karis, P.O., Lack, H.W., Nesom, G., Nordenstam, B., Oberpreiler, C., Panero, J.L., Puttock, C., Robinson, H., Stuessy, T.F., Susanna, A., Urtubey, E., Vogt, R., Ward, J. \& Watson, L.E. 2007. Compositae. In: Kadereit, J.W. \& Jeffrey, C. (eds.), The Families and Genera of Vascular Plants. Volume VIII. Flowering Plants. Eudicots. Asterales: 61-568. Springer. Berlin.

Andersson, S. 1996. Seed size as a determinant of germination rate in Crepis tectorum (Asteraceae): evidence from a seed burial experiment. Canadian Journal of Botany 74: 568-572.

Bastida, F. \& Menéndez, J. 2004. Germination requirements and disperal timing in two heterocarpic weedy Asteraceae. Communications in Agricultural and Applied Biological Sciences 69: 67-76.

Bastida, F., González-Andújar, J.L., Monteagudo, F.J. \& Menéndez, J. 2010. Aerial seed bank dynamics and seedling emergence patterns in two annual Mediterranean Asteraceae. Journal of Vegetation Science 21: 541-550.

Bello, M.A., Álvarez, I., Torices, R., Fuertes-Aguilar, J. 2013. Floral development and evolution of capitulum structure in Anacyclus (Anthemideae, Asteraceae). Annals of Botany (doi:10.1093/aob/mcs301).

Benard R.B., Toft C.A. 2007. Effect of seed size on seedling performance in a long lived desert perennial shrub (Ericameria nauseosa: Asteraceae). International Journal of Plant Sciences 168: 1027-1033.

Brändel, M. 2004. Dormancy and germination of heteromorphic achenes of Bidens frondosa. Flora 233: 228-233.

Brändel, M. 2007. Ecology of achene dimorphism in Leontodon saxatilis. Annals of Botany 100: 1189-1197.

Cousan, R., Dytham, C. \& Law, R. 2008. Dispersal in Plants. A population persepective. Oxford University Press. New York

Dubois, J. \& Cheptou, P.-O. 2012. Competition/colonization syndrome mediated by early germination in non-dispersing achenes in the heteromorphic species Crepis sancta. Annals of Botany 110: 1245-1251

Filho, S.P.R.M. \& Takaki, M. 2011. Dimorphic cypsela germination and plant growth in Synedrella nodiflora (L.) Gaertn. (Asteraceae). Brazilian Journal of Biology 71: 541-548.

Fumanal, B., Chauvel, B., Sabatier, A. \& Bretagnolle, F. 2007. Variability and cryptic heteromorphism of Ambrosia artemisiifolia seeds: what consequences for its invasion in France? Annals of Botany 100: 305-13.

Gadgil, M. 1971. Dispersal: population consequences and evolution. Ecology 52: 253-260.

Gillespie, J.H. 1977. Natural selection for variance in offspring numbers: a new evolutionary principle. American Naturalist 111: 1010-1014.

Gutterman, Y. 1994. Strategies of seed dispersal and germination in plants inhabiting deserts. The Botanical Review 60: 373-425.

Gutterman Y. \& Ginott, S. 1994. Long-term protected "seed bank" in dry inflorescences of Asteriscus pygmaeus; achene dispersal mechanism and germination. Journal of Arid Environments 26: 149-163.

Harper, J.L. 1977. Population biology of plants. Academic Press. Toronto.

Herrera, C.M. 2009. Multiplicity in Unity: plant subindividual variation and interactions with animals. The University of Chicago Press. London.

Humphries, C.J. 1979. A revision of the genus Anacyclus L. (Compositae: Anthemideae). Bulletin of the British Museum (Natural History) 7: 83-142.

Imbert, E. 2002. Ecological consequences and ontogeny of seed heteromorphism. Perspectives in Plant Ecology Evolution and Systematics 5: 13-36.

Imbert, E., Escarré J. \& Lepart J. 1996. Achene dimorphism and amongpopulation variation in Crepis sancta (Asteraceae). International Journal of Plant Sciences 157: 309-315.

Imbert, E. \& Ronce, O. 2001. Phenotypic plasticity for dispersal ability in the seed heteromorphic Crepis sancta (Asteraceae). Oikos 93: 126-134.

Koller, D. \& Roth, N. 1964. Studies of the ecological and physiological significance of amphicarpy in Gymnarrhena micrantha (Compositae). American Journal of Botany 51: 26-35.

Levin, S.A., Cohen, D. \& Hastings A. 1984. Dispersal strategies in patchy environments. Theoretical Population Biology 26: 165-191

Lu, J., Tan, D., Baskin, J.M. \& Baskin, C.C. 2010. Fruit and seed heteromorphism in the cold desert annual ephemeral Diptychocarpus strictus (Brassicaceae) and possible adaptive significance. Annals of Botany 105: 9991014

Manchester, S.R. \& O'Leary, E.L. 2010. Phylogenetic distribution and identification of fin-winged fruits. The Botanical Review 76: 1-82.

Mandák, B. 1997. Seed heteromorphism and the life cycle of plants: a literature review. Preslia 69: 129-159.

Maxwell, C.D., Zobel, A. \& Woodfine, D. 1994. Somatic polymorphism in the achenes of Tragopogon dubius. Canadian Journal of Botany 72: 12821288.

McEvoy, P.B. 1984. Dormancy and dispersal in dimorphic achenes of tansy ragwort. Oecologia 61: 160-168.

McGinley, M.A. 1989 Within and among plant variation in seed mass and pappus size in Tragopogon dubious. Canadian Journal of Botany 67: 12981304.

Meyer, S.E. \& Carlson, S.L. 2001. Achene mass variation in Ericameria nauseosus (Asteraceae) in relation to dispersal ability and seedling fitness. Functional Ecology 15: 274-281.

Orrock, J.L. \& Christopher, C.C. 2010. Density of intraspecific competitors determines the occurrence and benefits of accelerated germination. American Journal of Botany 97: 694-9.

Pandey, H.N. \& Dubey, S.K. 1988. Achene germination of Parthenium hysterophorus L.: effects of light, temperature, provenance and achene size. Weed Research 28: 185-190.

Parolin, P. 2006. Ombrohydrochory: Rain-operated seed dispersal in plants - With special regard to jet-action dispersal in Aizoaceae. Flora 201: 511518. 
Patterson, H.D. \& Thompson, R. 1971. Recovery of inter-block information when block sizes are unequal. Biometrica 58: 545-554

Peters, E.M., Martorell, C. \& Ezcurra, E. 2009. The adaptive value of cued seed dispersal in desert plants: Seed retention and release in Mammillaria pectinifera (Cactaceae), a small globose cactus. American Journal of Botany 96: 537-41.

Porras, R. \& Muñoz, J.M. 2000. Achene heteromorphism in the cleistogamous species Centaurea melitensis. Acta Oecologica 21: 231-243.

Prinzie, T.P. \& Chmielewski, J.G. 1994. Significance of achene characteristics and within- achene resource allocation in the germination strategy of tetraploid Aster pilosus var. pilosus (Asteraceae). American Journal of Botany 81: 259-264.

Rai, J.P.N. \& Tripathi, R.S. 1982. Adaptive significance of seed reserves in ray achenes of Galinsoga parviflora. Experientia 38: 804-806.

Redbo-Torstensson, P. \& Telenius, A. 1995. Primary and secondary seed dispersal by wind and water in Spergularia salina. Ecography 18: 230-237.

Rocha, O.J. 1996. The effects of achene heteromorphism on the dispersal capacity of Bidens pilosa L. International Journal of Plant Sciences 157:316322.

Ruiz de Clavijo, E. 1995. The ecological significance of fruit heteromorphism in the amphicarpic species Catananche lutea (Asteraceae). International Journal of Plant Sciences 156: 824-833.

Ruiz de Clavijo, E. 2005. The reproductive strategies of the heterocarpic annual Calendula arvensis (Asteraceae). Acta Oecologica 28: 119-126.

Ruiz de Clavijo, E. \& Jiménez, M.J. 1998. The influence of achene type and plant density on growth and biomass allocation in the heterocarpic annual Catananche lutea (Asteraceae). International Journal of Plant Sciences 159: 637-647.

Schoen, D.J. \& Lloyd, D.G. 1984. The selection of cleistogamy and heteromorphic diaspores. Biological Journal of the Linnean Society 23: 303-322.

Simons, A.M. 2011. Modes of response to environmental change and the elusive empirical evidence for bet hedging. Proceedings of the Royal Society $B$ 278: 1601-1609.

Sun, H.Z., Lu, J.J., Tan, D.Y., Baskin, J.M. \& Baskin, C.C. 2009. Dormancy and germination characteristics of the trimorphic achenes of Garbadiolus papposus (Asteraceae), an annual ephemeral from the Junggar Desert, China. South African Journal of Botany 75: 537-545.

Tackenberg, O., Poschlod, P. \& Bonn, S. 2003. Assessment of wind dispersal potential in plant species. Ecological Monographs 73: 191-205.
Tanowitz, B.D., Salopek, P.F. \& Mahall, B.E. 1987. Differential germination of ray and disc achenes in Hemizonia increscens (Asteraceae). American Journal of Botany 74: 303-312.

Telenius, A. \& Torstensson, P. 1989. The seed dimorphism of Spergularic marina in relation to dispersal by wind and water. Oecologia 80: 206210.

Thomson, F.J., Moles, A.T., Auld, T.D. \& Kingsford, R.T. 2011. Seed dispersal distance is more strongly correlated with plant height than with seed mass. Journal of Ecology 99: 1299-1307.

Tielbörger, K., Petruů , M., Lampei, C. 2012. Bet-hedging germination in annual plants: a sound empirical test of the theoretical foundations. Oikos 121: $1860-1868$.

Torices, R. \& Méndez, M. 2010. Fruit size decline from the margin to the center of capitula is the result of resource competition and architectural constraints. Oecologia 164: 949-958.

Van der Pijl, L. 1982. Principles of Dispersal in Higher Plant. Springer-Verlag. New York

Van Mölken, T., Jorritsma-Wienk, L.D., van Hoek, P.H.W. \& de Kroon, H 2005. Only seed size matters for germination in different populations of the dimorphic Tragopogon pratensis subsp. pratensis (Asteraceae). American Journal of Botany 92: 432-7.

Venable, D.L. 1985. Ecology of achene dimorphism in Heterotheca latifolia. III Consequences of varied water availability. Journal of Ecology 73: 757-763.

Venable, D.L. 2007. Bet hedging in a guild of desert annuals. Ecology 88: 1086-90.

Venable, D.L. \& Brown J.S. 1993. The population-dynamic functions of seed dispersal. Vegetatio 107/108: 31-55.

Venable, D.L., Búrquez, A., Corral, G., Morales, E. \& Espinosa, F. 1987. The ecology of seed heteromorphism in Heterosperma pinnatum in Central Mexico. Ecology 68: 65-76.

Verbeke, G. \& Molenberghs, G. 1997. Linear mixed models in practice. A SAS-oriented approach. Springer-Verlag. New York.

Zohary, M. 1950. Evolutionary trends in the fruiting head of Compositae. Evolution 4: 103-109.

Associate Editor: Javier Fuertes

Received: 4-XII-2012

Accepted: 30-III-2013 